\title{
Analysis of the Influential Factors of Manufactured Products Intra-Industry Trade between China-South Korea and China' Policy
}

\author{
Yan Li1 , Qing-Ling Dai' ${ }^{2}$ Qing-Bo Huang ${ }^{*}$ \\ ${ }^{1}$ Business and Economics Department, Transportation Management College, Dalian Maritime University, \\ Dalian, China \\ ${ }^{2}$ Huzhou Vocational \& Technical College, Huzhou, China \\ ${ }^{3}$ Business and Economics Department, Transportation Management College, Dalian Maritime \\ University, Dalian, China \\ Email: hqb4950@126.com
}

Received 23 January 2015; accepted 9 February 2015; published 13 February 2015

Copyright (C) 2015 by authors and Scientific Research Publishing Inc.

This work is licensed under the Creative Commons Attribution International License (CC BY).

http://creativecommons.org/licenses/by/4.0/

c) $\underset{\mathrm{EY}}{\mathrm{i}}$ Open Access

\begin{abstract}
In recent years, the trading contact between China and South Korea has become more and more close. In the 21st anniversary of the establishment of diplomatic relations between China and South Korea 2013, China has become South Korea's largest export market and largest import market. At the same time, South Korea has become China's fourth largest exporter and second largest importer of foreign trade, which contributes to the rapid development of manufactured products intraindustry trade between China and South Korea. This paper summarizes the development status of industrial manufactured products intra-industry trade between China and South Korea since 1992, and uses empirical analysis, then drawing a conclusion that the direct investment from South Korea to China, total merchandise trade between China and South Korea, and the economic development level of China have great influences on the level of intra-industry trade between China and South Korea, but the degree of the influence is different for different types of manufactured goods. Finally, this article proposes policy recommendations to promote the further development of manufactured products intra-industry trade between China and South Korea.
\end{abstract}

\section{Keywords}

Intra-Industry Trade, Manufactured Products, China and South Korea

\footnotetext{
${ }^{*}$ Corresponding author.
}

How to cite this paper: Li, Y., Dai, Q.-L. and Huang, Q.-B. (2015) Analysis of the Influential Factors of Manufactured Products Intra-Industry Trade between China-South Korea and China' Policy. Theoretical Economics Letters, 5, 114-124. 


\section{Introduction}

Since 1992, the diplomatic relations officially established between China and South Korea have continued to strengthen cooperation in various fields. One of the most particularly significant fields is in the trade. The form of commodity trade has changed from indirect trade to direct trade, and the trade volume between China and South Korea is increasing rapidly. At present, China has become South Korea's largest export market and largest import market. At the same time, South Korea has become China's fourth largest exporter and second largest importer. Between 1992 and 2013, China and South Korea's merchandise trade increases from \$5 billion to $\$ 274.2$ billion, increased by nearly 55 times. From 1992 to 2013, except in 1998 and 2009, influenced by the Asian Financial Crisis and the Global Financial Crisis, China and South Korea trade volume grows fast. Moreover, we can estimate that the export average annual growth is $22.02 \%$ from China to South Korea, and the import average annual growth is $24.23 \%$ from South Korea to China. It shows that during 1992-2013 the proportion of manufactured products in total commodity trade between China and South Korea is rising. From 1992 to 2013, the proportion of manufactured products in the total export trade between China and South Korea is rising from $47.10 \%$ to $92.25 \%$. Meanwhile, the proportion of manufactured products in the total import trade between China and South Korea is at a higher level of $90 \%$, which shows that since the establishment of diplomatic ties between China and South Korea. The main commodity export to South Korea from China gradually changes from primary products to manufactured products, and the main commodity import from South Korea in China is manufactured products. With the expansion of trade between China and South Korea, the intra-industry trade has gradually replaced the inter-industry trade, and become the main form of trade between the two countries. The trade between China and South Korea has always give priority to manufactured products, and intra-industry trade is mainly manufactured intra-industry trade. The development of intra-industry trade not only can promote the further economic and trade cooperation between the two countries, but also can promote the economic growth and the trade structure optimization between the two countries, so the manufactured products intra-industry trade of China and South Korea has important practical significance.

\section{Literature Review}

The Western economists studied on intra industry trade approximately experienced two stages. The first phase was before the middle of nineteen seventies. Many economists mainly judged the intra-industry trade by intuitive judgment and statistics. Verdoom (1960) analyzed the effect that "the Benelux union", then found that three countries specialization mainly occurs in the same industry between different branches. Mihchaely (1962) found rich countries' commodity structure was similarity after calculated 36 countries' 5 categories of STIC goods of the import and export. The second phase was after the middle of nineteen seventies. People mainly research on theoretical interpretation of statistical phenomenon. Grubel and Lloyd (1975) coauthored a book named "intraindustry trade: a differentiated product international trade theory and measure", this book is the first monograph on intra-industry trade. It is considered to be an important sign of change on the study of intra-industry trade, which from the empirical research to the theory research. In 1975 Grubel and Lloyd proposed G-L index, that can measure intra-industry trade. Jae Jin Byun (2001) continue Greenaway's ideas of horizontal and vertical intra-industry trade research, and calculated intra-industry trade on South Korea domestic industry. Finally found that actually South Korea's intra-industry trade was mainly vertical trade. It explained the changes of South Korea's industry trade level. At the same time, according to the results, in the overall analysis of the intra-industry trade factor is not very important, but in the horizontal and vertical intra-industry trade in a single analysis, factor's importance reflected. Brander and Krugman [1] explained the intra-industry trade of standardized products by constructed a Reciprocal Dumping Model. This model points out, because of oligopolistic interaction among the firms can lead to trade without any of the usual reasons among firms. Balassa [2] come to a conclusion that intra-industry trade and product differentiation are positive correlation, and intra-industry trade and scale economy or foreign direct investment are negatively related.

In our country, intra-industry trade theory and empirical analysis research has been a focus in the field of economics. In the aspect of theory, Jianhong Zhang (1995) analyzed the situation and reason of intra-industry trade between developed countries and developing countries. In 1997, the scholars had carried on the theoretical analysis on intra-industry trade in international trade. Jianhong Zhang (1997) studied intra-industry trade in our nation's international trade. After her, Jun Li (1998), Haiming Wei (1999), Sha Liu (2000) and so on also research on the theory of intra-industry trade. At that time, some Chinese economists apply the method of empiri- 
cal analysis to intra-industry trade in China. Quancheng Song (2003) used SITC1 and SITC2 classified methods, calculated our country's foreign trade intra-industry trade index from 2000 to 2002 year. Discovered that the processing trade development is the mainly reason of China's intra-industry trade growth. Wang [3] calculated 1993-2001 year between China and ASEAN's intra-industry trade index by using the G-L modified index model and computed the intra-industry trade's contribution rate to the increase of trade. Draw the conclusion that the intra-industry trade's contribution rate was significantly higher than inter-industry trade between China and ASEAN, and vertical intra-industry trade will become the characteristic in China and ASEAN intra-industry trade. Li [4] researched on the high-tech products intra-industry trade and calculated G-L modified index of the hightech products between China and America from 2002 to 2005 Years. Then found that the high-tech intra-industry trade's structural is instability, and different products obvious have different intra-industry trade level. Xu [5] studied the level of manufactured product intra-industry trade China and the European Union overall GL index and empirically the manufactured products, capital and technology intensive industry of GL index and the influence factors of labor-intensive industries in the GL index. Li [6] estimated the GL index of intra-industry trade level between China and South Korea. Tian Yan (2012) Korea calculated the SITC three digits GL index about manufactured products and the influence factors of manufactured products to intra-industry trade status quo are analyzed between China and South Korea.

Scholars at home and abroad are mainly use GL static index to research the level of the intra-industry trade of manufactured products between China and South Korea, rarely used dynamic index and classified index measuring intra-industry trade level. Most of them take manufactured products as the research object and less research on specific industry influence factors of manufactured products. This paper uses the data from 1992 to 2012, respectively adopt static index, dynamic index and classified index to measure intra-industry trade level between, and then uses empirical analysis methods to analyze the factors affecting the intra-industry trade of China and South Korea, finally puts forward policy suggestions to promote the development of intra-industry trade of China and South Korea further.

\section{The Empirical Analysis of Intra-Industry Trade in China and South Korea}

\subsection{The System of Intra-Industry Products Trade Index}

\subsubsection{Static Index}

The GL index created by Grubel and Lloyd in 1975, it is one of the most popular Static Index measures. This index is similar to measure the share of intra-industry in the trade. I will use the GL index to measure the static level of intra-industry trade in manufactured industry. This is the GL index formula: GL $i=[(\mathrm{Xi}+\mathrm{Mi})-\mid \mathrm{Xi}-$ $\mathrm{Mi}] /(\mathrm{Xi}+\mathrm{Mi})$. Xi refers to the export volume of product $\mathrm{i}$, Mi refers to the import volume of product $i$. The value of GL is between 0 and 1 , when GL index less than 0.25 intra-industry trade level is low; when GL index greater than or less than 0.25 or equal to 0.5 , intra-industry trade is in a lower level; when GL index greater than 0.5 and less than or equal to 0.5 , intra-industry trade at a higher level; When the GL index greater than 0.75 and less than or equal to 1, shows that intra-industry trade at a high level. According to the SITC (REV.3) standard, industrial manufactured products refer to 5 - 9 codes, because of the code of 9 is other products have not classified, so this article discusses the industrial manufactured goods only include the $5-8$ codes.

\subsubsection{Dynamic Index}

Owing to the GL index is a static index to measure the intra-industry trade, it can't reflect the change in intraindustry trade level in different period. If the import and export increase proportion are the same in a nation, the GL index would lapsed. Therefore, simply use GL index to measure the level of intra-industry trade is not comprehensive. I will introduce dynamic index (marginal intra-industry trade index, MIIT). The MIIT index first proposed by Brulhart (1994), the formula is: $M I I T i=(\Delta X i-|\Delta M i|) /(|\Delta X i|+|\Delta M i|)$. Brulhart points out that it is intra-industry trade, if a industry's absolute value of MIIT is less than 0.5. The absolute value of MIIT closer to 0 , the higher level of intra-industry trade is.

\subsubsection{Horizontal and Vertical Intra-Industry Trade Index}

The intra-industry trade can be divided into horizontal intra-industry trade and vertical intra-industry trade. Greenaway and Milner [7] proposed metric is widely used to distinct vertical and horizontal intra-industry trade. They consider that, if the value of $\mathrm{UV}_{\mathrm{x}}$ divided by $\mathrm{UV}_{\mathrm{m}}$ is between $1-\alpha$ and $1+\alpha$, the trade belongs to the in- 
tra-industry trade. If the value of $\mathrm{UV}_{\mathrm{x}}$ divided by $\mathrm{UV}_{\mathrm{m}}$ is less than $1-\alpha$ or larger than $1+\alpha$, the trade belongs to the vertical intra-industry trade. $\mathrm{UV}_{\mathrm{x}}, \mathrm{UV}_{\mathrm{m}}$ indicate the unit price of export, import products. $\alpha$ is a scatter factor, usually equals to 0.25 . That is to say, if the value of $P_{x}$ divided by $P_{m}$ is between 0.75 and 1.25 , the trade will be regarded as horizontal intra-industry trade. If the value of $\mathrm{P}_{\mathrm{x}}$ divided by $\mathrm{P}_{\mathrm{m}}$ is between 0 and 0.75 or bigger than 1.25 , the trade can be regarded as vertical intra-industry trade.

\subsection{The Result of Intra-Industry Products Trade Index}

\subsubsection{The Measurement Results of Static}

From the data in Table 1, China trade with South Korea always in a deficit state. But in particular, China's trade structure of South Korea is constantly improving. From constitute of manufactured products which China's import from South Korea, the proportion of Manufactured Goods Classified Chiefly by Material fell down 41\% from 1992 to 2013, and Chemicals and related products' proportion fell down 3.66\%, Machinery and transport equipment rise by $36 \%$, and miscellaneous products rose $11 \%$. From constitute of manufactured products which China export to South Korea, the proportion of Chemicals and related products, Machinery and transport equipment and Miscellaneous manufactured products rise by $1.1 \%, 46 \%$ and $7.5 \%$ respectively, but proportion of Manufactured Goods Classified Chiefly by Material e dropped by $9.6 \%$. Among them, the import proportion of Machinery and transport equipment is increased fastest, while the export proportion of Manufactured Goods Classified Chiefly by Material is dropped deepest. In addition, in 1992, the proportion of labor-intensive prod-

Table 1. The trade proportion of labor intensive and capital intensive products in export and import between China and South Korea from 1992 to $2013^{1}$.

\begin{tabular}{|c|c|c|c|c|c|c|c|c|}
\hline \multirow{2}{*}{ Year } & \multicolumn{4}{|c|}{$\begin{array}{l}\text { The import proportion of SITC5-8 } \\
\text { from South Korea to China }\end{array}$} & \multicolumn{4}{|c|}{$\begin{array}{l}\text { The export proportion of SITC5-8 } \\
\text { from South Korea to China }\end{array}$} \\
\hline & SITC5 & SITC6 & SITC7 & SITC8 & SITC5 & SITC6 & SITC7 & SITC8 \\
\hline 1992 & $20.56 \%$ & $49.62 \%$ & $17.31 \%$ & $2.81 \%$ & $6.78 \%$ & $29.33 \%$ & $4.16 \%$ & $6.82 \%$ \\
\hline 1993 & $16.90 \%$ & $46.79 \%$ & $20.91 \%$ & $4.22 \%$ & $7.41 \%$ & $26.41 \%$ & $7.09 \%$ & $13.47 \%$ \\
\hline 1994 & $19.41 \%$ & $43.74 \%$ & $23.85 \%$ & $4.46 \%$ & $8.24 \%$ & $30.15 \%$ & $8.24 \%$ & $17.20 \%$ \\
\hline 1995 & $22.99 \%$ & $39.42 \%$ & $22.89 \%$ & $5.25 \%$ & $9.42 \%$ & $41.52 \%$ & $10.03 \%$ & $14.82 \%$ \\
\hline 1996 & $20.00 \%$ & $39.97 \%$ & $25.55 \%$ & $5.71 \%$ & $7.54 \%$ & $33.08 \%$ & $15.72 \%$ & $15.42 \%$ \\
\hline 1997 & $21.25 \%$ & $37.84 \%$ & $23.56 \%$ & $5.30 \%$ & $6.60 \%$ & $34.07 \%$ & $16.35 \%$ & $14.39 \%$ \\
\hline 1998 & $24.64 \%$ & $37.87 \%$ & $21.85 \%$ & $4.39 \%$ & $7.72 \%$ & $26.89 \%$ & $23.81 \%$ & $14.36 \%$ \\
\hline 1999 & $21.87 \%$ & $36.21 \%$ & $26.51 \%$ & $4.09 \%$ & $7.65 \%$ & $27.60 \%$ & $25.47 \%$ & $14.75 \%$ \\
\hline 2000 & $22.11 \%$ & $31.38 \%$ & $30.84 \%$ & $3.83 \%$ & $6.82 \%$ & $25.11 \%$ & $26.57 \%$ & $16.10 \%$ \\
\hline 2001 & $22.11 \%$ & $29.74 \%$ & $32.89 \%$ & $4.43 \%$ & $6.95 \%$ & $21.04 \%$ & $29.09 \%$ & $18.63 \%$ \\
\hline 2002 & $20.17 \%$ & $23.43 \%$ & $42.83 \%$ & $6.89 \%$ & $6.56 \%$ & $22.09 \%$ & $28.68 \%$ & $20.78 \%$ \\
\hline 2003 & $16.66 \%$ & $19.74 \%$ & $44.16 \%$ & $12.94 \%$ & $6.36 \%$ & $22.05 \%$ & $30.54 \%$ & $20.42 \%$ \\
\hline 2004 & $16.70 \%$ & $16.77 \%$ & $43.25 \%$ & $16.51 \%$ & $5.92 \%$ & $25.66 \%$ & $36.62 \%$ & $16.70 \%$ \\
\hline 2005 & $17.04 \%$ & $14.77 \%$ & $45.77 \%$ & $16.39 \%$ & $6.47 \%$ & $27.52 \%$ & $35.81 \%$ & $13.78 \%$ \\
\hline 2006 & $16.63 \%$ & $12.96 \%$ & $47.36 \%$ & $15.15 \%$ & $6.83 \%$ & $30.61 \%$ & $35.29 \%$ & $14.43 \%$ \\
\hline 2007 & $17.18 \%$ & $11.39 \%$ & $47.22 \%$ & $16.29 \%$ & $7.02 \%$ & $31.06 \%$ & $36.47 \%$ & $13.16 \%$ \\
\hline 2008 & $17.53 \%$ & $10.92 \%$ & $45.09 \%$ & $15.93 \%$ & $6.72 \%$ & $33.07 \%$ & $39.22 \%$ & $10.80 \%$ \\
\hline 2009 & $17.30 \%$ & $11.11 \%$ & $46.85 \%$ & $17.46 \%$ & $7.19 \%$ & $21.37 \%$ & $48.83 \%$ & $12.53 \%$ \\
\hline 2010 & $15.91 \%$ & $9.52 \%$ & $48.90 \%$ & $18.26 \%$ & $8.04 \%$ & $23.16 \%$ & $46.48 \%$ & $13.30 \%$ \\
\hline 2011 & $16.81 \%$ & $8.98 \%$ & $47.16 \%$ & $16.95 \%$ & $8.90 \%$ & $24.68 \%$ & $43.20 \%$ & $14.28 \%$ \\
\hline 2012 & $16.54 \%$ & $8.21 \%$ & $49.90 \%$ & $15.85 \%$ & $7.74 \%$ & $21.83 \%$ & $48.08 \%$ & $14.22 \%$ \\
\hline 2013 & $16.90 \%$ & $8.61 \%$ & $53.68 \%$ & $13.89 \%$ & $7.88 \%$ & $19.71 \%$ & $50.36 \%$ & $14.31 \%$ \\
\hline
\end{tabular}

Source: <International Trade Statistics Yearbook> in recent Years.

${ }^{1}$ SITC6: Manufactured Goods Classified Chiefly by Material; SITC8: Miscellaneous manufactured. 
ucts import from South Korea to China was $52.43 \%$, which is $15 \%$ higher than capital and technology-intensive products, and the proportion of labor-intensive products exports from China to South Korea was $36.15 \%$, which is $25 \%$ higher than capital and technology intensive products. In 2013, the proportion of capital and technology intensive product imports from South Korea to China is $70.57 \%$, which is $48 \%$ higher than proportion of laborintensive products, at the same time, the proportion of the capital and technology-intensive products export from China to South Korea is $58.23 \%$, which is more than $24 \%$ higher than labor intensive product. This shows that the mainly product of China's import and export trade with South Korea change from the labor-intensive products to capital and technology-intensive products, the trade structure of China to South Korea has a greater degree of improvement.

The data of Table 2 show that more than half of the GL indexes are larger than 0.5 , which means that manufactured products trade between China and South Korea is mainly intra-industry trade, and that the intra-industry trade level of capital-intensive industries is higher than labor-intensive industries. Generally, in 1992, intra-industry trade index of Manufactured Goods Classified Chiefly by Material is highest, the second is Miscellaneous manufactured, however, Machinery and transport equipment and Chemicals and related products are the low, and focus on inter-industry trade. In 2013, Manufactured Goods Classified Chiefly by Material is still the highest, the GL index is 0.93, and Chemicals and related products is the lowest, the GL index is 0.38 . The intra-in- dustry trade level of Machinery and transport equipment has changed from the low degree to a higher degree of intra-industry trade. Miscellaneous manufactured is still in a state of intra-industry trade, but its level of intra- industry trade is obviously in a declining trend.

\subsubsection{The Measurement Results of Dynamic}

Table 3 shows that half of the MIIT values are greater than 0.5 from 1992 to 2013, it illustrates that the mainly type of trade between China and South Korea is inter-industry trade. In particular, it is obvious that SITC5 and SITC7 (the capital and technology intensive products) has the increase tendency in those intra-industry trade. The trade type of the Manufactured Goods Classified Chiefly by Material displaced intra-industry trade with inter-industry trade little by little, and the development status of miscellaneous manufactured is instability obviously. It is worthwhile to note that the trade type of SITC7 is in a high level of intra-industry trade according to the measurement of static index, but on the basis measurement of dynamic index, the trade type of SITC7 is inter-industry trade. From 1992 to 2012, basis on the static measurement, the trade type of Chemicals and related products is inter-industry all the time, but according to dynamic index, the trade type of SITC5 change into intra-industry trade after 2006. As the data shown, in recent years, the trade between China and South Korea is increasing. To some extent, this proved the limitation of using G-L static index in an empirical analysis only.

\subsubsection{The Measurement Results of Classified Index}

By Table 4, 1992-2013 the values of most of the Manufactured Goods Classified Chiefly by Material (SITC6)

Table 2. 1992-2013 the GL index of intra-industry trade of manufactured products.

\begin{tabular}{|c|c|c|c|c|c|c|c|c|c|}
\hline Year & SITC5 & SITC6 & SITC7 & SITC8 & Year & SITC5 & SITC6 & SITC7 & SITC8 \\
\hline 1992 & 0.46 & 0.70 & 0.36 & 0.62 & 2003 & 0.30 & 0.68 & 0.49 & 0.85 \\
\hline 1993 & 0.38 & 0.46 & 0.31 & 0.74 & 2004 & 0.27 & 0.81 & 0.55 & 0.62 \\
\hline 1994 & 0.41 & 0.59 & 0.34 & 0.60 & 2005 & 0.30 & 0.92 & 0.53 & 0.56 \\
\hline 1995 & 0.42 & 0.81 & 0.44 & 0.71 & 2006 & 0.34 & 0.92 & 0.54 & 0.64 \\
\hline 1996 & 0.37 & 0.66 & 0.54 & 0.76 & 2007 & 0.36 & 0.81 & 0.59 & 0.61 \\
\hline 1997 & 0.32 & 0.71 & 0.60 & 0.75 & 2008 & 0.40 & 0.67 & 0.73 & 0.62 \\
\hline 1998 & 0.23 & 0.46 & 0.63 & 0.85 & 2009 & 0.36 & 1.00 & 0.71 & 0.55 \\
\hline 1999 & 0.27 & 0.51 & 0.61 & 0.76 & 2010 & 0.40 & 0.91 & 0.64 & 0.53 \\
\hline 2000 & 0.26 & 0.56 & 0.59 & 0.66 & 2011 & 0.42 & 0.83 & 0.64 & 0.60 \\
\hline 2001 & 0.29 & 0.53 & 0.64 & 0.62 & 2012 & 0.39 & 0.84 & 0.67 & 0.64 \\
\hline 2002 & 0.30 & 0.68 & 0.53 & 0.76 & 2013 & 0.38 & 0.93 & 0.64 & 0.69 \\
\hline
\end{tabular}

Sources: UN comtrade. 
Table 3. 1992-2013 the MIIT index of manufactured products' intra-industry trade.

\begin{tabular}{ccccccccccc}
\hline Year & SITC5 & SITC6 & SITC7 & SITC8 & Year & SITC5 & SITC6 & SITC7 & SITC8 \\
\hline 1992 & - & - & - & - & 2003 & -0.69 & -0.29 & -0.60 & -0.61 \\
1993 & -0.76 & -0.92 & -0.73 & 0.18 & 2004 & -0.79 & 0.17 & -0.32 & -0.79 & -0.5 \\
1994 & -0.55 & -0.10 & -0.59 & 0.58 & 2005 & -0.62 & 0.47 & -0.55 & -0.85 \\
1995 & -0.56 & 0.26 & -0.33 & 0.05 & 2006 & -0.41 & 0.87 & -0.40 & 0.22 & -0.53 \\
1996 & -1.00 & -1.00 & -0.24 & -0.02 & 2007 & -0.52 & 0.91 & -0.14 & -0.53 \\
1997 & -0.90 & -0.02 & -0.02 & 0.33 & 2008 & -0.29 & 0.88 & 0.69 & -0.27 \\
1998 & -1.00 & -1.00 & 0.97 & -0.52 & 2009 & 0.26 & -0.88 & -0.05 & -1.00 \\
1999 & 0.25 & -0.08 & -0.44 & 0.70 & 2010 & -0.44 & 0.43 & -0.55 & -0.50 \\
2000 & -0.77 & -0.21 & -0.44 & 0.57 & 2011 & -0.49 & 0.52 & -0.40 & 0.08 & \\
2001 & 0.43 & 0.25 & 0.09 & 0.55 & 2012 & -1.00 & -0.28 & -0.08 & 1.00 & -0.58 \\
2002 & -0.60 & 1.00 & -0.70 & -0.02 & 2013 & -0.77 & -1 & -0.58 & 1.00 \\
\hline
\end{tabular}

Sources: UN comtrade.

Table 4. 1992-2012 the classified index of labor intensive products between China and South Korea ${ }^{2}$.

\begin{tabular}{|c|c|c|c|c|c|c|c|c|c|c|}
\hline $\mathbf{P}_{\mathbf{x}} / \mathbf{P}_{\mathbf{m}}$ & 653 & 657 & 673 & 675 & 682 & 871 & 874 & 884 & 893 & 899 \\
\hline 1992 & 1.73 & 0.66 & 0.71 & 0.90 & 0.90 & 0.37 & 0.02 & 0.25 & 0.76 & 0.34 \\
\hline 1993 & 1.55 & 0.81 & 0.80 & 3.03 & 1.26 & 0.24 & 0.02 & 0.04 & 0.91 & 0.17 \\
\hline 1994 & 1.44 & 0.93 & 0.73 & 1.00 & 0.93 & 2.53 & 0.01 & 0.03 & 1.04 & 0.38 \\
\hline 1995 & 1.18 & 1.01 & 0.74 & 1.56 & 1.05 & 1.45 & 0.01 & 0.02 & 1.13 & 0.31 \\
\hline 1996 & 0.83 & 0.93 & 0.68 & 1.47 & 1.00 & 2.37 & 0.01 & 0.02 & 0.71 & 0.77 \\
\hline 1997 & 1.00 & 0.76 & 0.70 & 1.15 & 0.95 & 11.20 & 0.01 & 0.01 & 0.02 & 0.83 \\
\hline 1998 & 0.82 & 0.89 & 0.73 & 0.53 & 0.89 & 2.20 & 0.02 & 0.02 & 0.62 & 0.74 \\
\hline 1999 & 0.84 & 0.71 & 0.59 & 0.40 & 0.94 & 1.42 & 0.13 & 0.01 & 0.59 & 0.58 \\
\hline 2000 & 0.80 & 0.75 & 0.63 & 1.08 & 0.97 & 0.01 & 0.13 & 1.21 & 0.41 & 0.54 \\
\hline 2001 & 0.66 & 0.82 & 0.58 & 0.97 & 0.98 & 0.00 & 0.02 & 0.82 & 0.43 & 0.62 \\
\hline 2002 & 1.60 & 0.84 & 0.68 & 0.89 & 0.91 & 0.00 & 0.02 & 0.66 & 0.04 & 0.68 \\
\hline 2003 & 0.52 & 0.69 & 0.68 & 1.33 & 1.14 & 0.07 & 0.41 & 3.84 & 1.20 & 0.42 \\
\hline 2004 & 0.55 & 0.65 & 0.88 & 1.09 & 1.17 & 0.08 & 0.38 & 5.01 & 0.48 & 0.45 \\
\hline 2005 & 0.61 & 0.62 & 0.76 & 1.11 & 1.20 & 1.05 & 0.38 & 0.97 & 0.48 & 0.35 \\
\hline 2006 & 0.60 & 0.54 & 0.75 & 1.12 & 1.13 & 0.60 & 0.42 & 1.66 & 0.48 & 0.41 \\
\hline 2007 & 0.60 & 0.54 & 0.80 & 1.04 & 1.12 & 0.65 & 0.55 & 2.88 & 0.40 & 0.49 \\
\hline 2008 & 0.83 & 0.50 & 1.06 & 0.52 & 1.14 & 0.74 & 0.61 & 3.89 & 0.45 & 0.47 \\
\hline 2009 & 1.21 & 0.55 & 0.99 & 0.54 & 1.06 & 0.90 & 0.40 & 5.38 & 0.48 & 0.44 \\
\hline 2010 & 0.52 & 0.58 & 0.71 & 0.64 & 0.93 & 1.00 & 0.54 & 7.97 & 0.49 & 0.51 \\
\hline 2011 & 0.56 & 0.56 & 0.86 & 0.57 & 0.96 & 1.35 & 0.26 & 11.07 & 0.52 & 0.58 \\
\hline 2012 & 0.49 & 0.47 & 0.83 & 0.48 & 0.95 & 0.52 & 0.28 & 10.97 & 0.64 & 0.65 \\
\hline 2013 & 0.52 & 0.46 & 0.84 & 0.52 & 0.86 & $*_{3}$ & * & $*$ & 0.65 & * \\
\hline
\end{tabular}

Source: UN comtrade.

${ }^{2}$ Above the selected three points product SITC6 and SITC8 is based on three points from 1992 to 2012 a total import and export of SITC6 and SITC8 accounted for the proportion of the total amount of import and export, the top five in the overall volume of trade to China and South Korea in 2012, the proportion of its trade accounted for more than $85 \%$, so these products reflects the overall trade situation has strong persuasive. 653: FABRICS, MAN-MADE FIBRES; 657: SPECIAL YARN, TXTL. FABRIC; 675: FLAT-ROLLED, ALLOY STEEL; 673: FLAT-ROLLED IRON ETC; 682: COPPER; 871: OPTICAL INSTRUMENTS, NES; 874: MEASUR, CONTROL INSTRMNT; 884: OPTICAL GOODS NES; 893: ARTICLES, NES, OFPLASTICS; 899: MISC MANUFCTRD GOOD SNES.

*Means can't find the data, and so as the next table. 
between China and South Korea about labor-intensive products trade is between 0.75 to 1.25 , in the horizontal intra-industry trade, while Miscellaneous manufactured (SITC8) classified index calculation values of most value to $0<\mathrm{P}_{\mathrm{x}} / \mathrm{P}_{\mathrm{m}}<0.75$ or $\mathrm{P}_{\mathrm{x}} / \mathrm{P}_{\mathrm{m}}>1.25$, shows that China and South Korea have miscellaneous manufactured intra-industry trade with vertical intra-industry trade level. Specifically, the value of copper (682) classified index is between 0.75 to 1.25 , shows that China and South Korea copper products trade in a horizontal intra-industry trade, special textile fiber yarn (657) and alloy steel products (675) shift the horizontal intra-industry trade into vertical intra-industry trade, iron, alloy steel (673) from the vertical intra-industry trade to horizontal intra- industry trade, synthetic fiber fabric (653) remains in the vertical intra-industry trade.

Table 5 shows that the classified index of the capital and technology-intensive products trade are mostly in the range of 0 to 0.75 or greater than 0.75 in 1992-2012 between china and Korea, which shows that the technology-intensive products trade of China and South Korea is given priority to with vertical intra-industry trade.

Table 5. 1992-2013 the classified index of technology intensive products between China and South Korea ${ }^{3}$.

\begin{tabular}{|c|c|c|c|c|c|c|c|c|c|c|}
\hline $\mathbf{P}_{\mathbf{x}} / \mathbf{P}_{\mathrm{m}}$ & 511 & 513 & 562 & 571 & 575 & 759 & 764 & 772 & 776 & 778 \\
\hline 1992 & 0.75 & 1.68 & 0.74 & 1.87 & 5.35 & 2.18 & 0.16 & 0.87 & 0.02 & 0.05 \\
\hline 1993 & 0.73 & 1.54 & 0.23 & 2.14 & 4.08 & 1.75 & 0.18 & 0.69 & 0.09 & 0.01 \\
\hline 1994 & 0.97 & 1.43 & 0.53 & 2.18 & 3.77 & 1.73 & 0.16 & 0.68 & 0.11 & 0.01 \\
\hline 1995 & 1.59 & 1.48 & 0.91 & 2.12 & 3.70 & 1.20 & 0.23 & 1.17 & 0.16 & 0.01 \\
\hline 1996 & 1.00 & 1.77 & 0.87 & 2.37 & 4.62 & 1.08 & 0.50 & 0.50 & 0.31 & 0.01 \\
\hline 1997 & 1.11 & 1.75 & 0.88 & 1.88 & 3.73 & 1.28 & 0.10 & 0.72 & 0.31 & 0.01 \\
\hline 1998 & 0.98 & 3.29 & 0.57 & 2.04 & 5.69 & 0.96 & 0.09 & 0.48 & 0.46 & 0.01 \\
\hline 1999 & 0.82 & 3.04 & 0.47 & 2.04 & 3.47 & 0.53 & 0.09 & 0.52 & 0.33 & 0.01 \\
\hline 2000 & 1.03 & 2.29 & 0.59 & 1.65 & 2.39 & 0.68 & 0.08 & 0.44 & 0.29 & 0.01 \\
\hline 2001 & 1.38 & 2.54 & 0.75 & 1.61 & 2.27 & 0.68 & 0.11 & 0.38 & 0.28 & 0.01 \\
\hline 2002 & 1.25 & 2.30 & 0.39 & 1.66 & 2.24 & 0.35 & 0.08 & 0.36 & 0.28 & 0.01 \\
\hline 2003 & 1.16 & 2.03 & 0.34 & 1.39 & 1.93 & 0.25 & 0.06 & 0.01 & 0.22 & 0.19 \\
\hline 2004 & 1.21 & 1.78 & 0.30 & 1.08 & 1.76 & 0.17 & 0.81 & 0.01 & 0.28 & 0.29 \\
\hline 2005 & 1.27 & 1.77 & 1.07 & 1.04 & 1.67 & 0.21 & 0.83 & 0.80 & 0.19 & 0.45 \\
\hline 2006 & 1.05 & 1.42 & 0.05 & 0.95 & 1.50 & 0.11 & 0.93 & 0.79 & 0.28 & 0.49 \\
\hline 2007 & 1.03 & 1.45 & 0.88 & 0.98 & 1.53 & 0.10 & 1.37 & 0.81 & 0.78 & 0.39 \\
\hline 2008 & 1.07 & 1.65 & 0.47 & 0.97 & 1.45 & 0.21 & 2.37 & 0.45 & 1.00 & 0.43 \\
\hline 2009 & 1.18 & 1.54 & 0.50 & 1.11 & 1.75 & 0.16 & 2.52 & 0.38 & 0.82 & 0.37 \\
\hline 2010 & 1.26 & 1.57 & 0.58 & 1.07 & 1.58 & 0.18 & 2.70 & 0.54 & 0.73 & 0.40 \\
\hline 2011 & 1.38 & 1.26 & 0.32 & 1.02 & 1.59 & 0.17 & 2.40 & 0.51 & 0.72 & 0.41 \\
\hline 2012 & 1.35 & 1.38 & 0.46 & 1.04 & 1.53 & 0.23 & 2.47 & 0.45 & 0.58 & 0.43 \\
\hline 2013 & 1.11 & 1.35 & 0.34 & 1.02 & 1.40 & 0.17 & $*$ & 0.51 & * & * \\
\hline
\end{tabular}

Source: UN Comtrade.

\footnotetext{
${ }^{3}$ Above the selected three points product SITC5 and SITC7 is based on three points from 1992 to 2012 a total import and export of SITC5 and SITC7 accounted for the proportion of the total amount of import and export, the top five in the overall volume of trade to China and South Korea in 2012, the proportion of its trade accounted for more than $85 \%$, so these products reflects the overall trade situation has strong persuasive. 511: HYDROCARBONS. NES, DERIVTS; 513: CAROXYLICACIDS, DERIVTS; 562: FERTILIZER, EXCEPT GRP 272; 571: POLYMERS OFSTYRENE; 575: PLASTI, PROMARY FORM; 759: PARTS, FOR OFFICE MACHINS; 764: TELECOMM.EQUIP.PARTS NES; 772: ELEC.SWITCH.RELAY.CIRCUT; 776: TRANSISTORS, VALVES, ETC; 778: ELECTRI.MACH.APPART.NES.
} 
Specifically, SITC5 types of carboxylic acid (513), chemical fertilizers (562) and other primary plastic products (575) three products always in a state of vertical intra-industry trade level, hydrocarbons (511) has been belong to the horizontal intra-industry trade before 2009 , however, the development trend of the vertical intra- industry trade after 2009, the classified index of five product in SITC7 categories are mostly not between 0.75 to 1.25 , which shows that China and South Korea machinery and transport equipment and other products is given priority to with vertical intra-industry trade.

All in all, from the point of the dynamic analysis results, China and South Korea still is given priority to vertical manufactured products. This phenomenon may be due to the difference of income gap between the two countries consumer's preferences. In recent Years, although the economical in our country have made a great progress, China and South Korea is still having a large gap in the level of per capita GDP. According to World Bank database statistics show that in 1992 China's per capita GDP is $\$ 362.81$, and South Korea is $\$ 7555.27$, which is 21 times of China's. With the rapid development of economy in China, China's per capita GDP in 2013 reach to $\$ 6747$, and South Korea's per capita GDP is \$24329, 3.6 times higher than China's per capita GDP. Due to per capita GDP of China and South Korea have bigger difference, contributes the two countries have different requirements to the same quality and price of goods. In addition, the manufactured products of China and South Korea give priority to vertical can also be caused by the technological gap of differences in production and the level of export commodities.

\section{The Empirical Analysis of the Affecting Factors of Intra-Industry Trade between China and South Korea}

\subsection{Variables Selection and Data Sources}

This article takes the intra industry trade level (GL) as the dependent variable. There are five explanatory variables, direct investment from South Korea to China (South Korea direct investment to China, FDI), the market size both in China and South Korea (the average GDP of China and South Korea, ES), the per capita GDP gap in China and South Korea ((the per capita GDP of South Korea-the per capita GDP of China)/(the per capita GDP of South Korea + the per capita GDP of China), PGDP), economy scale in industrial of China (the proportion of the added value of above scale industrial in China's GDP, INDS) and technological progress in China (exports of China's high-tech products accounted for the proportion of China's industrial manufactured goods exports, TP) from 1992 to 2012 years.

The data of Intra-industry trade level and China's export of industrial manufactured goods are from the United Nations Comtrade database. The statistics of the proportion of the added value of above scale industrial in China's GDP and direct investment from South Korea to China are from the $<$ Chinese Statistical Yearbook $>$. The per capita GDP of China and South Korea are from World Bank Database. The data of China's high-tech products exports from the web site of Ministry of Science and Technology of China.

\subsection{Measuring Model}

This article uses the GL Indexes of SITC5, SITC6, SITC7, and SITC8 as the explanatory variables. In order to avoid the impact of heteroscedasticity in the time series of economic data, all variables are taken from the actual value in the natural logarithmic form. Considering the investment has lagged behind, this paper uses the firstorder lag of investment as explanatory variables in regression analysis. The regression models are established as follows:

$$
\ln G L i=\alpha+\beta_{1} \ln F D I(-1)+\beta_{2} \ln E S+\beta_{3} \ln P G D P+\beta_{4} \ln I N D S+\beta_{5} \ln T P+\mu
$$

GLi respectively refer to GL5, GL6, GL7 and GL8, and indicates the intra-industry trade levels of SITC5, SITC6, SITC7 and SITC8, so there are four equations, they are Equations (1), (2), (3), (4), $\alpha$ is a constant, $\mu$ is the random error.

\subsection{Results of Empirical Analysis}

The article uses the statistical analysis software Eviews 6.0 to carry on regression analysis to Equations (1) and (2) respectively, and the results are shown in Table 6. According to the first regression results, in Equations (1) and (4) the direct investment from South Korea to China (FDI) did not pass the t-test; economy scale in industry 
Table 6. The coefficients of SITC5-8 in regression results.

\begin{tabular}{ccccccccc}
\hline & \multicolumn{3}{c}{ The first regression results } & \multicolumn{5}{c}{ The second regression results } \\
\cline { 2 - 6 } & GL5 & GL6 & GL7 & GL8 & GL5 & GL6 & GL7 & GL8 \\
\hline LnFDI $(-1)$ & -0.03 & $0.16^{* *}$ & $0.12^{*}$ & 0.01 & $-0.08^{* 4}$ & $0.12^{* *}$ & $0.07^{*}$ & $0.07^{* 5}$ \\
LnES & $1.98^{* *}$ & $2.67^{* *}$ & $-1.98^{*}$ & -0.29 & $1.82^{* *}$ & $3.02^{* *}$ & $-2.28^{* *}$ & $-0.09^{*}$ \\
LnPGDP & $-1.50^{* *}$ & $-2.19^{* *}$ & $1.99^{* *}$ & 0.16 & $-1.36^{* *}$ & $-2.55^{* *}$ & $2.17^{* *}$ & - \\
LnINDS & 0.19 & 0.14 & -0.15 & $-0.30^{*}$ & $0.23^{*}$ & - & - & $-0.39^{* *}$ \\
LnTP & $-0.32^{* *}$ & -0.15 & 0.14 & 0.05 & $-0.25^{*}$ & - & - & - \\
C & $-8.51^{* *}$ & $-10.26^{* *}$ & $4.21^{* *}$ & 2.01 & $-8.13^{* *}$ & $-10.74^{* *}$ & $4.91^{*}$ & $1.59^{* *}$ \\
R-squared & 0.88 & 0.82 & 0.83 & 0.56 & 0.91 & 0.80 & 0.79 & 0.63 \\
DW & 1.80 & 2.21 & 1.40 & 1.85 & 2.17 & 2.10 & 1.15 & 1.64 \\
\hline
\end{tabular}

Notes: ${ }^{*}$ indicates that passing the test at a significant level of $1 \%$; ${ }^{*}$ indicates passing at a significant level of $5 \%$.

al of China (INDS) only past the $t$ test in Equation (4); technological progress in China (TP) only past the t-test in Equation (1); the market size both in China and South Korea (ES) and the per capita GDP gap between China and South Korea (PGDP) haven't passed the t-test in Equation (4). In order to get a more accurate model, this paper uses variable elimination method and concludes the model that shown in the second regression results in Table 6.

According to the second regression results, we find that all the coefficients of the explanatory variables of SITC5-8 passed the t-test, $\mathrm{R}^{2}$ is large, and the value of DW is closed to 2, which indicates the fitting degree of the equation is good and the multi-co-linearity doesn't exist. Therefore, this article ultimately chose second regression results to explain the bilateral trade of manufactured products between China and South Korea, and the regression equation as follows:

$$
\begin{gathered}
\ln G L 5=-0.08 \ln F D I(-2)+1.82 \ln E S-1.36 \ln P G D P-0.25 \ln T P-8.13 \\
\ln G L 6=0.12 \ln F D I(-1)+3.02 \ln E S-2.55 \ln P G D P-10.74 \\
\ln G L 7=0.07 \ln F D I(-1)-2.28 \ln E S+2.17 \ln P G D P+4.91 \\
\ln G L 8=0.07 \ln F D I(-2)-0.09 \ln E S-0.39 \ln I N D S+1.59
\end{gathered}
$$

From the above equation, we know that the coefficient of FDI in Equations (2), (3) and (4) are all positive, however, the coefficient of FDI in Equation (1) is negative. This shows that the direct investment from South Korea to China has a positive impact to the intra-industry trade in Manufactured Goods Classified Chiefly by Material, Machinery and transport equipment and Miscellaneous manufactured. The probable reason of this phenomenon is South Korea's labor costs rising since the nineteen nineties. At that time, South Korea began to shift less competitive manufactured to China, and used China's cheap labor to product core components of Manufactured Goods Classified Chiefly by Material, Machinery and transport equipment and Miscellaneous manufactured, and this core components returned to South Korea. Therefore, South Korea investment in China is conducive to the intra-industry trade in Manufactured Goods Classified Chiefly by Material, Machinery and transport equipment and Miscellaneous manufactured. However, South Korea's investment to China has a negative impact to Chemicals and related products. This may be related to South Korea's policy. In nineteen nineties, in order to improve the pace of the development economic, South Korea government began to increase the intensity of support to the heavy chemical industry. Chemical products benefit from domestic industry policy and financial policy support, so that its development level is significantly higher than that of our country. As a result, South Korea invest to China in Chemical and related products is mainly vertical industrial division, so South Korea invest to this kind of products result to strong trade substitution effect.

The coefficient of market size of China and South Korea (ES) in Equations (1) and (2) are positive, but in

\footnotetext{
${ }^{4,5}$ This Coefficient is the result of $\operatorname{Ln} F D I(-2)$.
} 
Equations (3) and (4) the coefficient are negative. Meanwhile, these coefficients are big. This shows that the market size of China and South Korea has a big positive impact on the intra-industry trade in Chemical related products and Manufactured Goods Classified Chiefly by Material. But there is negative impact on intra-industry trade between China and South Korea of Machinery and transport equipment and Miscellaneous manufactured.

The explanatory variables of per capita GDP gap in China and South Korea (PGDP) in Equations (1), (2) and (3) are passed the t-test, but isn't passed in Equation (4). This refers that PGDP have some extent impact on the intra-industry trade of Chemical and related products, Manufactured Goods Classified Chiefly by Material, Machinery and transport equipment. In addition, there is a negative correlation among PGDP, Manufactured Goods Classified Chiefly by Material and chemical and related products. And there is a positive relation between PGDP and Machinery and transport equipment's intra-industry trade. However, the PGDP influence on miscellaneous products industry of China and South Korea trade is not significant.

The coefficient of economy scale in industrial of China (INDS) in Equations (1) and (4) are passed the t-test, but it isn't passed in Equations (2) and (3). This shows that INDS has a certain influence on the level of intraindustry trade in chemical related products and miscellaneous products, but for Manufactured Goods Classified Chiefly by Material and Machinery and transport equipment, the impact is not significant. In addition, there exists the positive impact on between INDS and the intra-industry level of chemistry related products trade, but INDS have a negative impact on miscellaneous products' level of intra-industry in China and South Korea.

The explanatory variables of technological progress in China (TP) only in Equation (1) passed the t-test, and as a negative. Meanwhile, in Equations (2), (3) and (4) it isn't through the significant test. This suggests that China's technological progress only have influence to the intra-industry trade level of chemical related products, and this influence is negative. However, the TP influence on the level of intra-industry trade in Manufactured Goods Classified Chiefly by Material, Machinery and transport equipment and Miscellaneous manufactured is not significant.

\section{Conclusion and Policy Suggestions}

\subsection{Conclusion}

As the trade and economic cooperation of China and South Korea is more and more closing, it is very important to develop the intra-industry trade, especially the main trade products between China and South Korea tradeindustrial manufactured goods. This paper uses the static index (GL), dynamic index (MIIT) and classified index to measure the level of intra-industry trade in Industrial manufactured goods, takes the GL index of four types' industrial manufactured goods as the explanatory variable, and analyses those influence factors. The study finds that the level of manufactured goods trade is intra-industry trade between China and South Korea, but there is a big difference in the trade level of different types in industrial manufactured goods. The intra-industry trade level of capital and technology products in the trade between China and South Korea is high and rises rapidly. Although the intra industry trade index of chemical products declined in the wave, it is still dominated by intraindustry trade status. In addition, the level of intra industry trade index in labor intensive products is higher than that of capital and technology intensive products. According to the econometric analysis, direct investment from South Korea to China, the market size both in China and South Korea, all of the per capita GDP gap in China and South Korea, economy scale in industrial of China and technological progress in China have influences on the level of intra-industry trade between China and South Korea, but the degree of the influence on industrial manufactured goods on different types is different.

\subsection{Policy Suggestions}

\subsubsection{Pushing the Bilateral Cooperation to a Higher Level in the Field of Investment}

In the term of South Korea's investment to China, on one hand, China should pay attention to adjust the direction of the investment of Korean companies and actively take advantage of these investments to improve China's industrial structure; on the other hand, China should improve the scale structure of Korean enterprises to increase the large enterprise groups' interests to invest in China. In addition, the two countries should also pay attention to strengthen their cooperation in the central and western regions of China to promote the coordinated development of regional economy with the Korean investment. Meanwhile, China should accelerate the pace of investing to South Korea; China's enterprises should increase productive investment to Korea and respond posi- 
tively to the national call for "going out" strategy. By doing so, it can not only make the bilateral cooperation more balanced, but also can drive China's exports to South Korea and reduce China's trade deficit, so as to promote the balanced development of bilateral trade.

\subsubsection{Increasing Investment of Research and Development (R \& D) and Improving the Industrial Structure of China}

It has been a long time that China's capital-and-technology-intensive products trade maintains a high deficit with South Korea. The reality warns us that the development of China's capital and technology intensive industries is not fast enough. China has become the world's third-largest trading country; it's time for us to make our efforts to change our country from a large trading nation into a powerful one. Therefore, adjusting and improving the industrial policy reasonably, guiding and encouraging the development of electronic machineries, communications equipments and other products with high technology and high degree of product differentiation, improving the quality and technical content of the related intermediate products, utilizing the development of key components to drive the development of the related producing processes, all of which will be conducive to the optimization of the structure of China's commodities and the enhancement of the international competitiveness of products!

\subsubsection{Promoting the Transformation and Upgrading of Processing Trade between China and South Korea}

The current development level of China's processing trade is quite low and mainly based on the industrial vertical division of labor, which are expressed in the lower additional value and technical content. The key to the development of processing trade is that the government should strengthen the supervision and guidance and promote the transformation and upgrading of processing trade from the vertical division of labor to the horizontal division. The future of China's processing trade should focus on key industries. Meanwhile, China should also implement the "import substitution" policy on some of the sophisticated products, especially on the intermediate products. Turing the imports of some of the raw materials and intermediate goods into domestic procurement and gradually promoting the processing trade from primary to senior through the establishment of key industries for the development of processing trade and the import substitution of certain intermediate products, so as to promote the rapid development of the intra-industry trade between the two countries.

\section{Fund Program}

Liaoning province social science fund project (L14AJY001): Liaoning province fund project of finance scientific research (14D008); Basic scientific research fund project of central university (3132015052).

\section{References}

[1] Brander, J. and Krugman, P. (1983) A "Reciprocal Dumping” Model of International Trade. Journal of International Economics, 15, 3-321. http://dx.doi.org/10.1016/S0022-1996(83)80008-7

[2] Bela, B. (1986) The Determinants of Intra-Industry Specialization in United States Trade. Oxford Economic Review, 38.

[3] Wang, J. (2004) An Analysis with Substantial Evidence on the Developmental Trend of Trade in Sino-ASEAN Industries. All-Round Southeast Asia, 6, 33-37.

[4] Li, D. (2006) The Empirical Research on the Intra-Industry Trade in Sino-US ATP Trade. The Journal of Quantitative \& Technical Economics, 8, 90-97.

[5] Xu, C.S. and Deng, Q.Z. (2007) Intra-Industry Trade and Its Determinants of Manufactured Goods between China and EU. Journal of International Trade, 7, 45-49.

[6] Li, D. (2007) Empirical Analysis on the Intra-Industry Trade between China and South Korea. Journal of International Trade, 4, 49-54.

[7] Greenaway, D. and Milner, C. (1994) Country-Specific Factors and the Pattern of Horizontal and Vertical Intra-Industry Trade in the UK. Weltwirtschaftliches Archive, 130. 
Scientific Research Publishing (SCIRP) is one of the largest Open Access journal publishers. It is currently publishing more than 200 open access, online, peer-reviewed journals covering a wide range of academic disciplines. SCIRP serves the worldwide academic communities and contributes to the progress and application of science with its publication.

Other selected journals from SCIRP are listed as below. Submit your manuscript to us via either submit@scirp.org or Online Submission Portal.
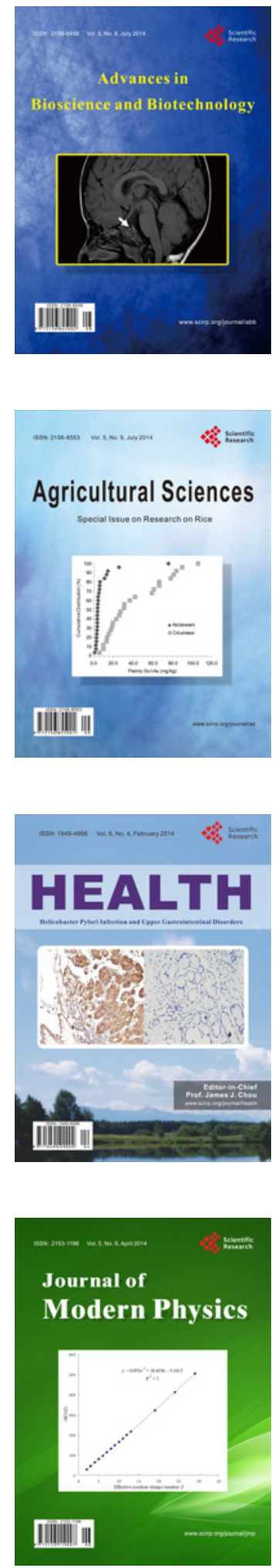
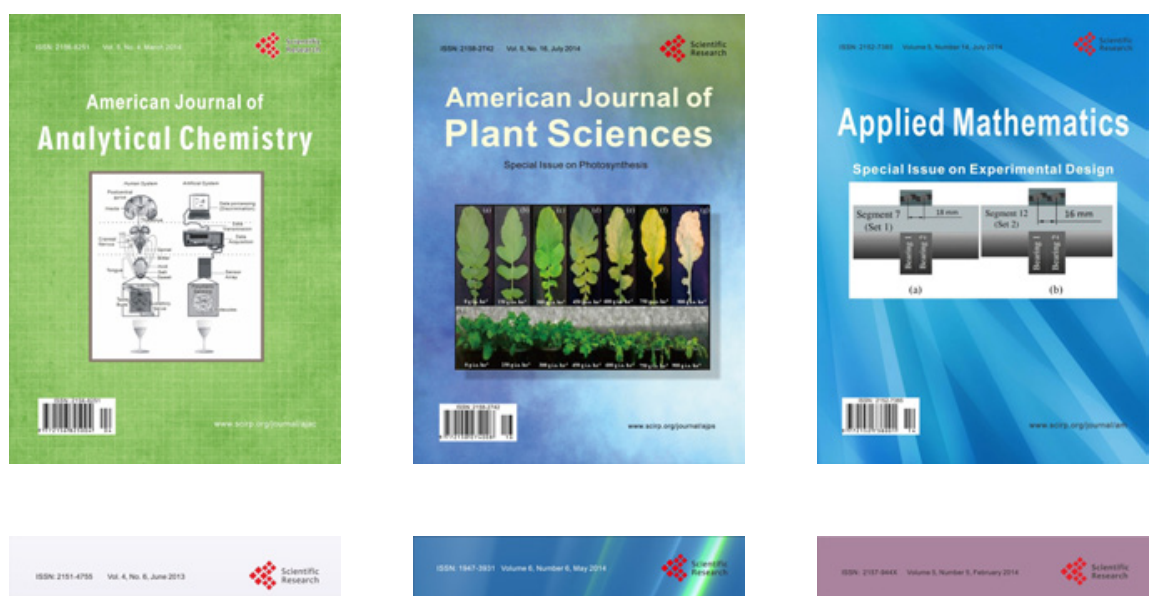

Creative Education
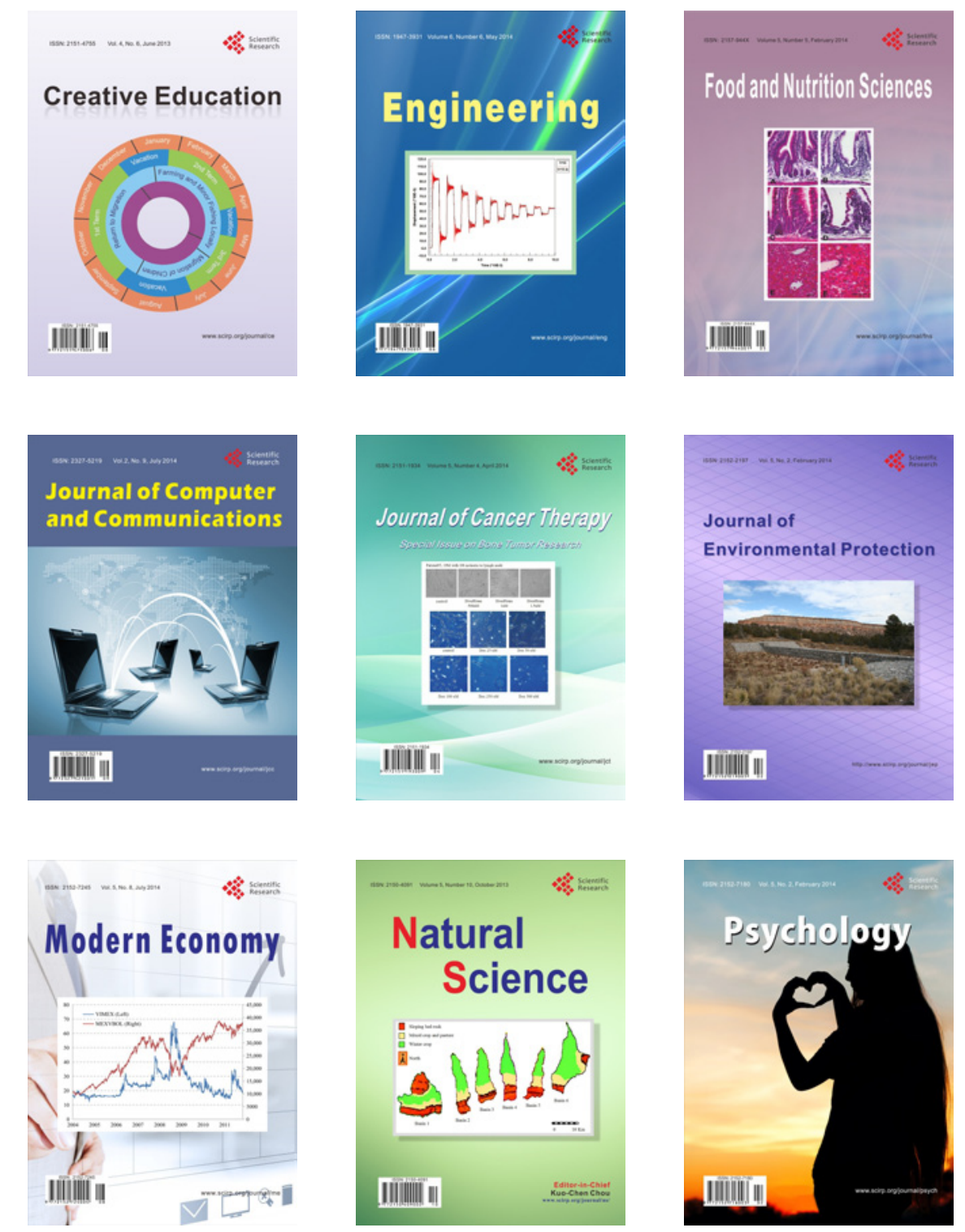